\title{
Does Insurance Development Affect Financial Market in Developing Countries?
}

\author{
Relwendé Sawadogo \\ Centre d'Etudes et de Recherches sur le Développement International \\ University of Auvergne, France \\ E-mail: Relwende.Sawadogo@etu.udamail.fr \\ Samuel Guerineau \\ Centre d'Etudes et de Recherches sur le Développement International \\ University of Auvergne, France \\ E-mail: samuel.guerineau@udamail.fr
}

Received: May 8, 2016

doi:10.5296/ifb.v3i1.9533
Accepted: May 23, 2016

Published: June 7, 2016

URL: http://dx.doi.org/10.5296/ifb.v3i1.9533

\begin{abstract}
This paper investigates the impact of insurance on stock market development in 37 developing countries over the period 1987-2011. By controlling for the potential endogeneity bias by System GMM estimator, we show that the insurance premiums significantly increase the stock market value traded. This result is robust to the use of alternative measure of stock market development and control of the political and legal system quality. In addition, the results highlight that an improvement in property rights promotes the deepening of the financial market. Thus, the results argue for insurance policies promoting and an improvement of the legal environment to benefit from the financial market development.
\end{abstract}

Keywords: Stock market, Insurance premiums, Developing countries, Panel data 


\section{Introduction}

Since UNCTAD (Note 1) report in 1982 showing the importance of insurance promotion for the economic development in developing countries, several studies have addressed this issue as well in the developed, emerging and developing countries. Most of these studies have analyzed the insurance effect on economic growth (Webb et al., 2002; Ward \& Zurbruegg, 2000; Arena, 2008; Avram et al., 2010; Outreville, 2011; Chang \& Lee, 2012) and insurance direct effect on the development of financial market has been less analyzed. However, the insurance companies just like other institutional investors may not only help to improve the allocation of capital on financial market, but also strengthen their investments through enhanced surveillance (Masci et al., 2007). Capital markets may also be a driving force for the benefit of the development of institutional investors. Given that, the insurance companies have of the products whose maturities are lengthy, they are a natural complement for the development of capital markets (Masci et al., 2007). Furthermore, the insurance companies have large cash inflows and reserves (linked to payment of premiums), whose a portion may be invested in less liquid instruments such as the bonds and equities. In this context, the development of insurance services plays a primordial role in the development of financial markets through the risk management, savings allocation and financial market growth.

The previous literature has shown that the development of contractual savings activities (pension funds and insurance companies), which constitute the main institutional investors, contributes to the development of financial markets (Viattas, 1998; Catalan et al., 2000). Indeed, the development of contractual savings can have at once a direct and indirect impact on the development of financial markets. The direct impact is linked to modification of composition of the supply of funds in economy: the relative supply of long term funds increases, which translates into an increased demand for the instruments of the market capital. Thus, the development of contractual savings promotes depth and liquidity of capital markets, and improves financial structure of enterprises and governments by increasing the equity to debt ratio and lengthening the maturity of debt (Impavido \& Musalem, 2000). Regarding the indirect impact, the institutional investor development can lead an improving to efficiency of financial market by encouraging the other financial intermediaries and the corporate sector to more specialization and professionalism (Dickinson, 2000).

There are a few empirical studies on the relationship between the assets generated by the contractual savings institutions and financial market development. These studies concern the countries of OECD and some emerging countries (Catalan et al., 2000; Impavido et al., 2003). Indeed, Catalan et al. (2000) found that the development of life insurance and pension funds to Granger-cause the development of capital markets in countries of OECD. In regards to Impavido et al. (2003); they showed firstly that an increase in assets of contractual savings institutions relative to assets of the domestic financial system has a positive impact on the deepening of stock and bond markets. Then, the impact of contractual savings development on stock market development is amplified in countries where the information on the companies is more transparent. Finally, they highlighted a significant heterogeneity between countries as a function of the nature of their financial system. 
However, though the previous studies bring a significant contribution to analysis of the effects of the development of insurance companies on capital market, they are not exempt from criticism. First, they do not take into account the developing countries which the two systems (insurance and financial markets) are experiencing a significant evolution and constitute an important potential sources of long-term financing. Secondly, the previous studies do not distinguish between the effect of different contractual savings companies (insurance and pension funds) on stock market development while unlike to the developed countries, in developing countries the insurances are more developed than the pension funds.

The goal of this chapter is to contribute to literature by testing effect of the development of insurance activity on the development of financial market. Thus, we analyze the impact of the insurance activities development on stock market transaction value in a sample of 37 developing countries over the period 1987-2011 (Note 2). Indeed, OECD report in 2014 on the cooperation for the development has shown that contractual savings companies constitute a potential source for long-term financing in development countries. Thereby, we think that, this study will allow us to prove empirically whether the development of insurance sector contributes effectively to functioning of stock markets in developing countries. Finally, unlike to the existing literature (Catalan et al., 2000; Impavido et al., 2003), we also try to control the quality of institutions and legal system in the development of stock markets. This is justified in literature ( $\mathrm{La}$ Porta et al., 1998) who showed that the financial system is developing rapidly in countries where there is more of protection of investor rights and an independence of the judicial system in the settlement of commercial disputes.

The rest of the chapter is articulated as follows. The section 2 shows econometric model and the estimate strategy. The section 3 presents data of the study. The section 5 is consecrated to interpretation the mains results and the last section concludes the paper.

The rest of the paper is articulated as follows. The section 2 shows the econometric model and the estimate strategy. The section 3 presents the data of the study. The section 5 is consecrated to the interpretation the mains results and the last section concludes the paper.

\section{Empirical Approach}

Does insurance penetration (i.e., insurance premiums to GDP) affect the stock market development? To understand the impact of insurance development on stock market development, we estimate the following regression:

$$
\text { Stocktra }_{i, t}=\alpha+\beta_{1} * I N S_{i, t}+\beta_{2} * X_{i, t}+\eta_{i}+\varepsilon_{i t}
$$

Where, Stocktra ${ }_{i, t}$ is a measure of the financial market development level and $I N S_{i, t}$ is the proxy for insurance sector development for the country $i$ in period $t$. $X$ represents a vector of the control variables identified in literature as determinants of stock market. $\alpha, \beta_{1}$ and $\beta_{2}$ are unknown parameters to be estimated. $\eta$ and $\varepsilon$ are country fixed effects and the idiosyncratic error term, respectively.

In line with the empirical work of the factors of financial market development (Yartey, 2008), we control for the initial real GDP per capita, domestic investment to GDP, ratio of domestic 
credit allocated to private sector to GDP, inflation, real interest rate and foreign direct investment as a percentage of GDP (FDI). Unlike previous studies, we also control the institutions quality and legal system by the protection of Property Rights, Legal System and Property Rights and Rule of Law (Note 3). Control variables are from World Development Indicators (WDI) and the indicators of the quality of intuitions come from Economic Freedom of the World Index, Fraser Institute and International Country Risk Guide (ICRG).

The estimate of our equation (1) above runs against to the traditional problems of endogeneity, originating from of simultaneity bias. Indeed, insurance development could be also influenced by the stock market development; for example a stock market development could improve the financial results of the insurance companies and lead to an increase of their activities: which increases the confidence of economic agents to consume the assurance (Beck \& Webb 2003). In order to control this potential simultaneity bias, we estimate the equation of stock market development well as his transformation in first differences as a system of equations by using the System GMM estimator developed by Blundell \& Bond (1998).

Indeed, System GMM estimator allows not only to take into account the heterogeneity of countries, but also to treat the problem of endogeneity of variables that may arise in our relationship between stock market development and insurance penetration. This estimator consists to combine for each period the equation in levels and the equation in first differences which allows for the use of lagged differences and lagged levels of the explanatory variables as instruments (Blundell and Bond 1998). We use Windmeijer (2005) finite-sample correction to the standard errors in two-step estimation. Instrumentation procedure was performed so as to limit the problem of too many instruments (Roodman et al., 2009) (Note 4).

Panel data are averaged over nonoverlapping five-year on the period 1987-2011 as follows: 1987-1991, 1992-1996, 1997-2001, 2002-2006 and 2007-2011. This approach has been also used by Beck \& Levine (2004). Furthermore, in our estimates, we estimate the impact of insurance on stock market on whole the period (1987-2011) and period before financial crisis (1987-2006). Estimation of insurance effect on financial market before crisis (1987-2011) is justified by the fact that financial crisis has mainly affected financial market and banking. Thus, given that stock market has experienced a crisis, insurance effect on this latter could be more influenced by the financial crisis that enabled the insurance companies to develop by proposing of savings products less volatile.

\section{Data and Summary Statistics}

This section describes the variables and provides the summary statistics (see Table 1). Devising an indicator for stock market development is not an easy task at all. Ideally, such an indicator should simultaneously reflect liquidity, volume of transactions, informational efficiency, degree of concentration, volatility, depth, legal and institutional, and other factors that determine the overall performance of a stock exchange. In this study, we use stock market transaction ratio which is equal stock market total value traded to GDP. It is an indicator of deepening of financial market and measures liquidity of stock market by relative to size of economy. This indicator has the advantage to take into account both size and 
activity of stock market (Čihák et al., 2012). Thus, it is used as a good proxy for the development of stock markets. Regarding to indicator of the development of insurance activities, it is expressed by the total premiums to GDP. It measures total revenue of insurance companies relative to economy activity. These two indicators of stock market and insurance development are derived from the Benchmarking financial systems around the world developed by Čihák et al. (2012).

Table 1 presents the descriptive statistics of our different variables for sample of 37 developing countries (Note 5). We observe that average of period 1987-2007, stock market transaction ratio represents 6.71 times the insurance penetration. Regarding the average of the bank credit ratio, it represents more than 16 times insurance penetration and more than 2 times the stock market transactions ratio on period 1987-2011. These show that insurance sector is poorly developed in relation to other financial institutions (banks and stock markets). As indicated also in table 6.1, there are of significant variations in financial market transaction ratio in the different countries. For example, average of period 1987-2011, stock market value traded to GDP varies from $0.0116 \%$ of GDP in Bolivia to $200.831 \%$ of GDP in Singapore. In return, insurance penetration rate varies from $0.166 \%$ of GDP in Bangladesh 17 . $469 \%$ in South Africa over the same period.

Table 1. Summary statistics

\begin{tabular}{|l|l|l|l|l|l|}
\hline Variables & Obs & Mean & Std. Dev. & Min & Max \\
\hline Stock market total value traded (\% GDP) & 760 & 15.3429 & 29.5049 & 0.0116 & 200.8311 \\
\hline Insurance Premiums (\% GDP) & 735 & 2.2863 & 2.3156 & 0.166 & 17.469 \\
\hline Domestic investment (\% GDP) & 931 & 21.4512 & 6.5289 & 5.4589 & 45.9602 \\
\hline Private credit by deposit money banks (\% GDP) & 912 & 38.4634 & 30.5436 & 2.0848 & 165.8018 \\
\hline Initial GDP per capita & 881 & 3576.983 & 4411.472 & 260.7826 & 34758.41 \\
\hline Real interest rate & 733 & 7.9709 & 12.4303 & -58.3547 & 78.7899 \\
\hline FDI (\%GDP) & 938 & 3.0963 & 3.7916 & -12.2084 & 27.8737 \\
\hline Property Rights & 413 & 5.0864 & 1.5919 & 1.1666 & 9.2043 \\
\hline Legal System and Property Rights & 512 & 5.2803 & 1.3422 & 1.9532 & 8.9683 \\
\hline Rule of Law & 852 & 3.2146 & 1.2477 & 0 & 6 \\
\hline
\end{tabular}

Source: Čihák et al. (2012), World Bank, ICRG, and authors' calculations

The figure 1 shows evolution of stock market total value traded to GDP and insurance premiums as a percentage of GDP in our sample of countries. One notice the two curves have similar evolutions serrated with an increasing general tendency during period of study. This situation shows that the two financial sectors are sensitive to economic situation of countries. Indeed, we observe an increase of stock market transaction after the years 2000 but until now a strong decrease in early 2008 following the financial crisis. However, insurance penetration knows a growth despite the crisis. This situation of insurance sector may be explained by several arguments. Firstly, the divergence of evolution can be explained by the fact that the two financial sectors are not affected in same way by the financial crisis, especially that a 
large part of assets of insurance companies in developing countries are bank deposits and government securities that are disconnected from world financial markets. Then, insurance sector could develop because stock and banking markets are in crisis: the insurance companies stronger and less affected (by their nature) by the stock market fluctuations could benefit from the crisis on stock market by providing the products less volatiles. Finally, one can also think that increase of insurance activities is explained by economic growth in developing countries especially in emerging countries leading to an increase of insurance demand.

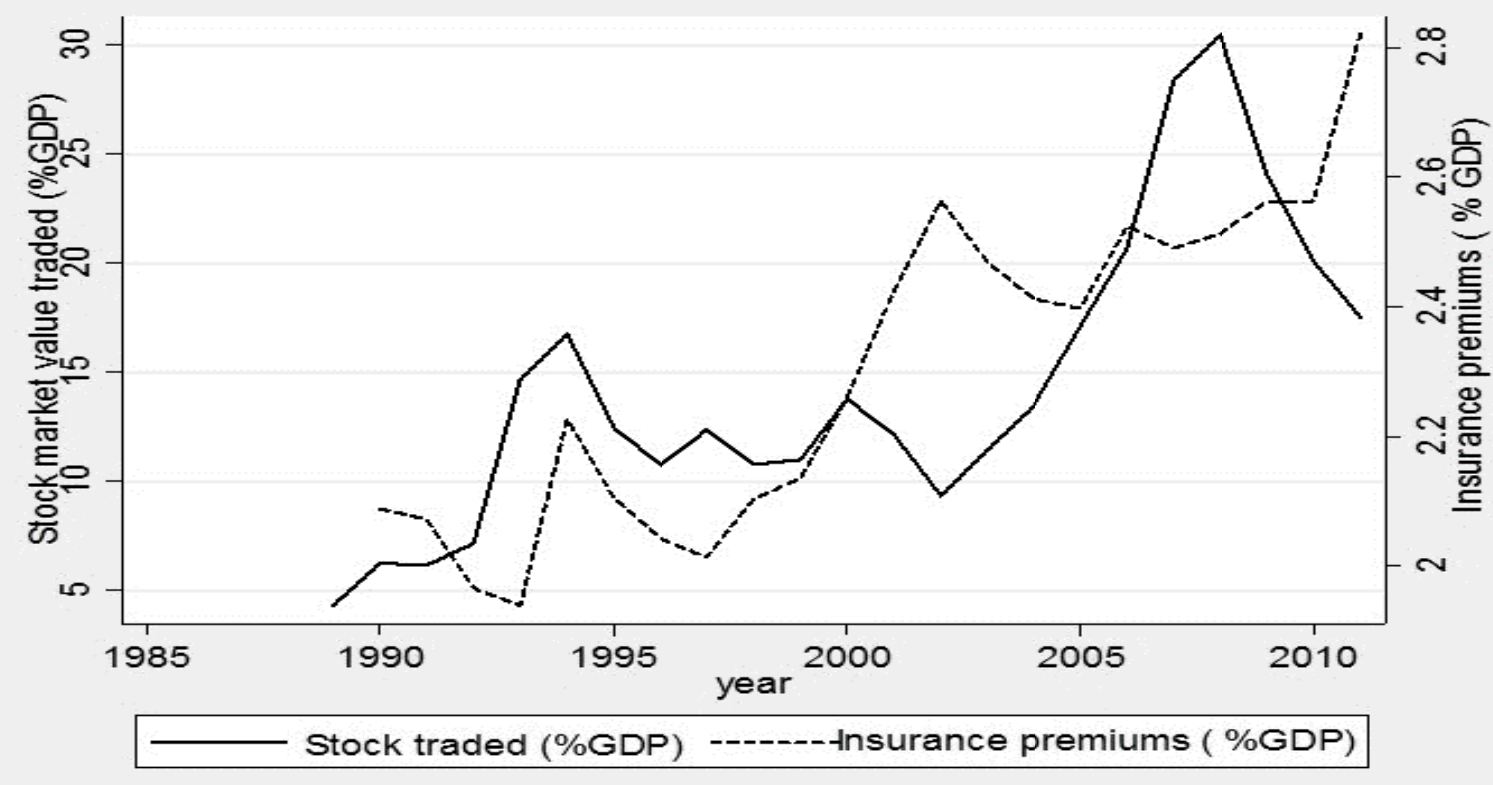

Figure 1. Stock market value traded to GDP and Insurance premiums to GDP (1987-2011) Source: Čihák et al. (2012) and authors' calculations

\section{The Results of the Estimations}

The results of the estimations are presented in Table 2. Thus, columns 1 to 4 have been estimated by considering the period from 1987 to 2011 and columns 5 to 8 for the period 1987-2006. Consistent with the findings of earlier empirical studies (Impavido et al., 2003), the regressions results in Table 2 show that countries with higher levels of insurance sector development experienced higher levels of stock market development over period 1987-2011, even when one controls the effect of GDP per capita and development financial (Note 6). Coefficient of insurance penetration range from 3.152 to 4.885 and from 4.219 to 6.760 for the period 1987-2011 and 1987-2006 respectively. Indeed, the positive effect of the insurance premiums in all the regressions means that the development of insurance contributes to stock market development in developing countries. Thus, the increase in insurance premiums allows the insurance companies to have sufficient resources for long-term investments and hold the less liquid assets in their portfolios more profitable; which contributes to improve equity trading. 
Among the control variables, only domestic investment has a positive and significant effect in the period from 1987 to 2011 (column 2, 3 and 4). This suggests that, on average, the countries with domestic investments rise have tendency to experience the higher levels of stock trading that the countries with the less investment. Thus, increased investment improves the development of financial market by means of the demand of funds to finance certain investments particularly heavy. This result is conformed the work of Yartey (2008).

Table 2. The impact of insurance development on financial market

\begin{tabular}{|c|c|c|c|c|c|c|c|c|}
\hline \multirow{2}{*}{$\begin{array}{l}\text { Dependent Variable: } \\
\text { Stock market total } \\
\text { value traded ( } \% \text { GDP) }\end{array}$} & \multicolumn{4}{|c|}{$\begin{array}{l}\text { Averaged over fixed non-overlapping five-year } \\
\text { periods between } 1987 \text { and } 2011\end{array}$} & \multicolumn{4}{|c|}{$\begin{array}{l}\text { Averaged over five-year periods between } 1987 \\
\text { and } 2006\end{array}$} \\
\hline & $(1)$ & (2) & (3) & (4) & $(5)$ & $(6)$ & (7) & $(8)$ \\
\hline Lagged dependent & $\begin{array}{l}0.822 * * * \\
(0.1857)\end{array}$ & $\begin{array}{l}0.846 * * * \\
(0.1398)\end{array}$ & $\begin{array}{l}0.793 * * * \\
(0.2505)\end{array}$ & $\begin{array}{l}0.782 * * * \\
(0.1374)\end{array}$ & $\begin{array}{l}0.792 * * * \\
(0.23812)\end{array}$ & $\begin{array}{l}0.9831 * * * \\
(0.40434)\end{array}$ & $\begin{array}{l}0.8404 * * \\
(0.3167)\end{array}$ & $\begin{array}{l}0.857 * * \\
(0.30475)\end{array}$ \\
\hline $\begin{array}{l}\text { Insurance Premiums } \\
(\% \text { GDP })\end{array}$ & $\begin{array}{l}3.152 * * * \\
(1.2747)\end{array}$ & $\begin{array}{l}3.694 * * * \\
(0.9385)\end{array}$ & $\begin{array}{l}4.298 * * * \\
(1.57247)\end{array}$ & $\begin{array}{l}4.885 * * * \\
(1.34167)\end{array}$ & $\begin{array}{l}4.219^{*} \\
(2.271)\end{array}$ & $\begin{array}{l}5.4887 * \\
(2.7290)\end{array}$ & $\begin{array}{l}5.14423^{*} \\
(3.0235)\end{array}$ & $\begin{array}{l}6.760 * * \\
(2.7362)\end{array}$ \\
\hline Initial GDP per capita & $\begin{array}{l}0.00028 \\
(0.0008)\end{array}$ & $\begin{array}{l}0.00026 \\
(0.0010)\end{array}$ & $\begin{array}{l}0.000126 \\
(0.00134)\end{array}$ & $\begin{array}{l}-0.00136 \\
(0.0018)\end{array}$ & $\begin{array}{l}-0.00093 \\
(0.00076)\end{array}$ & $\begin{array}{l}-0.0011 \\
(0.0009)\end{array}$ & $\begin{array}{l}-0.00082 \\
(0.0008) \\
\end{array}$ & $\begin{array}{l}-0.00331 \\
(0.00216) \\
\end{array}$ \\
\hline Investment & & $\begin{array}{l}1.6987 * \\
(0.9834)\end{array}$ & $\begin{array}{l}1.83963 * * \\
(0.8889)\end{array}$ & $\begin{array}{l}1.5645 * * \\
(0.7067)\end{array}$ & & $\begin{array}{l}1.3796 \\
(1.115)\end{array}$ & $\begin{array}{l}1.29927 \\
(1.55622)\end{array}$ & $\begin{array}{l}1.41616 \\
(0.9557)\end{array}$ \\
\hline $\begin{array}{l}\text { Private credit ( } \% \\
\text { GDP) }\end{array}$ & & $\begin{array}{l}-0.2500 \\
(0.2134)\end{array}$ & $\begin{array}{l}-0.22264 \\
(0.2949)\end{array}$ & $\begin{array}{l}-0.20887 \\
(0.1648)\end{array}$ & & $\begin{array}{l}-0.3190 \\
(0.4386)\end{array}$ & $\begin{array}{l}-0.15656 \\
(0.44033)\end{array}$ & $\begin{array}{l}-0.23626 \\
(0.2652)\end{array}$ \\
\hline Inflation & & $\begin{array}{l}-0.0023 \\
(0.00266)\end{array}$ & & $\begin{array}{l}0.00490 \\
(0.0061)\end{array}$ & & $\begin{array}{l}-0.00124 \\
(0.0033)\end{array}$ & & $\begin{array}{l}0.009153 \\
(0.0069)\end{array}$ \\
\hline Real interest rate & & & $\begin{array}{l}0.10758 \\
(0.1732)\end{array}$ & & & & $\begin{array}{l}0.07346 \\
(0.2034)\end{array}$ & \\
\hline FDI & & & & $\begin{array}{l}2.4348 \\
(2.0463)\end{array}$ & & & & $\begin{array}{l}3.56144 \\
(2.48871)\end{array}$ \\
\hline Constant & $\begin{array}{l}-1.75268 \\
(2.7752) \\
\end{array}$ & $\begin{array}{l}-29.262^{*} \\
(16.2078)\end{array}$ & $\begin{array}{l}-34.502 * * \\
(14.832) \\
\end{array}$ & $\begin{array}{l}-33.634 * * \\
(13.7140)\end{array}$ & $\begin{array}{l}-2.7848 \\
(3.4952)\end{array}$ & $\begin{array}{l}-19.8536 \\
(21.0170) \\
\end{array}$ & $\begin{array}{l}-24.6745 \\
(25.4759) \\
\end{array}$ & $\begin{array}{l}-32.2126 \\
(21.424)\end{array}$ \\
\hline $\begin{array}{l}\text { Observations } \\
\text { Countries } \\
\text { AR(1): p-value } \\
\text { AR(2):p-value } \\
\text { Hansen OID test: } \\
\text { prob. } \\
\text { Instruments }\end{array}$ & $\begin{array}{l}126 \\
37 \\
0.043 \\
0.325 \\
0.194 \\
24\end{array}$ & $\begin{array}{l}122 \\
36 \\
0.052 \\
0.195 \\
0.106 \\
26\end{array}$ & $\begin{array}{l}105 \\
33 \\
0.040 \\
0.266 \\
0.278 \\
26\end{array}$ & $\begin{array}{l}122 \\
36 \\
0.044 \\
0.187 \\
0.270 \\
27\end{array}$ & $\begin{array}{l}89 \\
36 \\
0.097 \\
0.290 \\
0.404 \\
15\end{array}$ & $\begin{array}{l}86 \\
35 \\
0.089 \\
0.224 \\
0.106 \\
17\end{array}$ & $\begin{array}{l}75 \\
32 \\
0.029 \\
0.303 \\
0.169 \\
17\end{array}$ & $\begin{array}{l}86 \\
35 \\
0.030 \\
0.187 \\
0.305 \\
18\end{array}$ \\
\hline
\end{tabular}

Note. The estimation method is the two-step System-GMM method with the Windmeijer (2005) correction for finite sample bias. Robust standard errors are reported in parentheses. AR (1): and AR (2): denote the Arellano and Bond statistics tests for lack of one-order and second-order serial correlation, respectively $* \mathrm{P}<0.1, * * \mathrm{p}<$ $0.05, * * * \mathrm{p}<0.01$. All the variables of the model are assumed to predetermined and instrumented by their delays at most 5 periods

We also explore the robustness of our results by controlling effect of legal system quality on the development of stock market using always the system GMM estimator. The results are presented in Table 3. The results with the control variables of legal system quality are robust because we find positive effect of insurance on stock market development in all the regressions (column 1 to 6). Moreover, we observed that, protection of property rights has a positive and significant impact on stock market (column 1 and 4) while the index of legal 
system and property rights and rule of law have not the significant effect. Thus, the positive impact of the index of property rights (column 1 and 4) confirms that the development of stock market just like the others financial services (insurance, pension funds, banks) requires a good legal framework which supports property rights (Avram et al., 2010). The underlying theory is that in countries with more secure property rights, firms might allocate resources better and consequently grow faster as the returns on different types of assets are more protected (Claessens \& Laeven, 2003).

Table 3. Robustness: control of the legal system quality

\begin{tabular}{|c|c|c|c|c|c|c|}
\hline \multirow{2}{*}{$\begin{array}{l}\text { Dependent Variable: Stock } \\
\text { market total value traded } \\
(\% \text { GDP })\end{array}$} & \multicolumn{3}{|c|}{$\begin{array}{l}\text { Averaged over fixed non-overlapping } \\
\text { five-year periods between } 1987 \text { and } 2011 .\end{array}$} & \multicolumn{3}{|c|}{$\begin{array}{l}\text { Averaged over five-year periods } \\
\text { between } 1987 \text { and } 2006\end{array}$} \\
\hline & $(1)$ & $(2)$ & (3) & $(4)$ & $(5)$ & (6) \\
\hline Lagged dependent & $\begin{array}{l}0.6294 * * * \\
(0.1512)\end{array}$ & $\begin{array}{l}0.74914 * * * \\
(0.2129)\end{array}$ & $\begin{array}{l}0.81193 * * * \\
(0.16438)\end{array}$ & $\begin{array}{l}0.79249 * * * \\
(0.17387)\end{array}$ & $\begin{array}{l}0.85635^{* * *} \\
(0.2348)\end{array}$ & $\begin{array}{l}0.51165 * * \\
(0.2137)\end{array}$ \\
\hline $\begin{array}{l}\text { Insurance Premiums } \\
(\% \text { GDP })\end{array}$ & $\begin{array}{l}3.3462 * * \\
(1.06106)\end{array}$ & $\begin{array}{l}3.2023 * * \\
(1.2604)\end{array}$ & $\begin{array}{l}3.3848 * * * \\
(0.93829)\end{array}$ & $\begin{array}{l}4.15298 \\
(3.1244)\end{array}$ & $\begin{array}{l}4.4453 * \\
(2.2125)\end{array}$ & $\begin{array}{l}3.0841 * * * \\
(0.6978)\end{array}$ \\
\hline Initial GDP per capita & $\begin{array}{l}-0.00042 \\
(0.00098)\end{array}$ & $\begin{array}{l}0.000026 \\
(0.0009)\end{array}$ & $\begin{array}{l}0.000213 \\
(0.00089)\end{array}$ & $\begin{array}{l}-0.001172 \\
(0.00082) \\
\end{array}$ & $\begin{array}{l}-0.00099 \\
(0.00105)\end{array}$ & $\begin{array}{l}-0.00031 \\
(0.0007)\end{array}$ \\
\hline Investment & $\begin{array}{l}1.05875 \\
(1.0185) \\
\end{array}$ & $\begin{array}{l}1.07215 \\
(0.8691) \\
\end{array}$ & $\begin{array}{l}1.4856 * * \\
(0.6871)\end{array}$ & $\begin{array}{l}-0.09044 \\
(0.89774) \\
\end{array}$ & $\begin{array}{l}0.2849 \\
(0.9678)\end{array}$ & $\begin{array}{l}1.21444 \\
(0.7977)\end{array}$ \\
\hline Private credit ( $\%$ GDP $)$ & $\begin{array}{l}0.00904 \\
(0.10891)\end{array}$ & $\begin{array}{l}0.05698 \\
(0.08489)\end{array}$ & $\begin{array}{l}-0.16882 \\
(0.17414) \\
\end{array}$ & $\begin{array}{l}-0.15888 \\
(0.15978) \\
\end{array}$ & $\begin{array}{l}-0.05178 \\
(0.07231)\end{array}$ & $\begin{array}{l}-0.00998 \\
(0.2523)\end{array}$ \\
\hline Inflation & $\begin{array}{l}0.13777 \\
(0.52299) \\
\end{array}$ & $\begin{array}{l}-0.00049 \\
(0.0038)\end{array}$ & $\begin{array}{l}-0.0082 \\
(0.00543) \\
\end{array}$ & $\begin{array}{l}0.075605 \\
(0.4003) \\
\end{array}$ & $\begin{array}{l}-0.00221 \\
(0.0053)\end{array}$ & $\begin{array}{l}-0.00586 \\
(0.0044)\end{array}$ \\
\hline Property Rights & $\begin{array}{l}5.51697 * \\
(2.87303) \\
\end{array}$ & & & $\begin{array}{l}9.527^{*} \\
(4.835) \\
\end{array}$ & & \\
\hline $\begin{array}{l}\text { Legal System and Property } \\
\text { Rights }\end{array}$ & & $\begin{array}{l}-1.02215 \\
(3.98351) \\
\end{array}$ & & & $\begin{array}{l}0.77905 \\
(5.58861) \\
\end{array}$ & \\
\hline Rule of Law & & & $\begin{array}{l}0.25228 \\
(2.59211) \\
\end{array}$ & & & $\begin{array}{l}0.73026 \\
(2.86048) \\
\end{array}$ \\
\hline Constant & $\begin{array}{l}-49.5726^{*} \\
(25.2566) \\
\end{array}$ & $\begin{array}{l}-20.0594 \\
(15.0164) \\
\end{array}$ & $\begin{array}{l}-27.3459 * * \\
(12.1434)\end{array}$ & $\begin{array}{l}-24.9415 \\
(20.18919) \\
\end{array}$ & $\begin{array}{l}-9.22052 \\
(18.6563) \\
\end{array}$ & $\begin{array}{l}-24.8703^{*} \\
(13.1495) \\
\end{array}$ \\
\hline $\begin{array}{l}\text { Observations } \\
\text { Number of id } \\
\text { AR(1): p-value } \\
\text { AR(2):p-value } \\
\text { Hansen OID test: prob. } \\
\text { Instruments }\end{array}$ & $\begin{array}{l}73 \\
33 \\
0.030 \\
0.886 \\
0.108 \\
24\end{array}$ & $\begin{array}{l}121 \\
36 \\
0.037 \\
0.241 \\
0.220 \\
28\end{array}$ & $\begin{array}{l}116 \\
34 \\
0.028 \\
0.132 \\
0.167 \\
27\end{array}$ & $\begin{array}{l}40 \\
27 \\
0.020 \\
0.730 \\
0.571 \\
15\end{array}$ & $\begin{array}{l}85 \\
34 \\
0.080 \\
0.283 \\
0.267 \\
19\end{array}$ & $\begin{array}{l}82 \\
33 \\
0.020 \\
0.139 \\
0.139 \\
18\end{array}$ \\
\hline
\end{tabular}

Note. The estimation method is the two-step System-GMM method with the Windmeijer (2005) correction for finite sample bias. Robust standard errors are reported in parentheses. AR (1): and AR (2): denote the Arellano and Bond statistics tests for lack of one-order and second-order serial correlation, respectively $* \mathrm{P}<0.1, * * \mathrm{p}<$ $0.05, * * * \mathrm{p}<0.01$. All the variables of the model are assumed to predetermined and instrumented by their delays at most 5 periods. The Legal System and Property Rights, measure of the quality of a country's legal system and protection of property rights is from the Economic Freedom of the World Index, Fraser Institute.

The second analysis of robustness considers an alternative measure of stock market development, namely the stock market capitalization to GDP. Contrary the stock market total value traded to GDP which measures stock market liquidity, market capitalization represents size of stock market in domestic economy. This measure is equal to the value of listed shares 
divided by GDP. The market capitalization as a percentage of GDP was used in several empirical studies as a proxy of the development of stock market (see Levine \& Zervos, 1998; Boyd et al., 2001; Beck \& Levine, 2004). As for the stock market total value traded to GDP, there is wide variation in stock market capitalization to GDP on average of period 1987-2011, ranging from less than $0.190 \%$ in Latvia to more than $328.876 \%$ in Malaysia.

Table 4. Robustness: Alternative measure of stock market development

\begin{tabular}{|c|c|c|c|c|c|c|c|c|}
\hline \multirow{2}{*}{$\begin{array}{l}\text { Dependent Variable: } \\
\text { Stock market } \\
\text { capitalization ( GDP) }\end{array}$} & \multicolumn{4}{|c|}{$\begin{array}{l}\text { Averaged over fixed non-overlapping five-year } \\
\text { periods between } 1987 \text { and } 2011 \text {. }\end{array}$} & \multicolumn{4}{|c|}{$\begin{array}{l}\text { Averaged over five-year periods between } 1987 \text { and } \\
2006\end{array}$} \\
\hline & $(1)$ & $(2)$ & (3) & (4) & $(5)$ & $(6)$ & $(7)$ & $(8)$ \\
\hline Lagged dependent & $\begin{array}{l}0.30602 * * \\
(0.1217)\end{array}$ & $\begin{array}{l}0.25187 * * * \\
(0.087)\end{array}$ & $\begin{array}{l}0.24601 * * \\
(0.0931)\end{array}$ & $\begin{array}{l}0.1170 \\
(0.111) \\
\end{array}$ & $\begin{array}{l}0.1043 \\
(0.084) \\
\end{array}$ & $\begin{array}{l}0.07510 \\
(0.0546)\end{array}$ & $\begin{array}{l}0.06646 \\
(0.0586)\end{array}$ & $\begin{array}{l}-0.05653 \\
(0.1311) \\
\end{array}$ \\
\hline $\begin{array}{l}\text { Insurance Premiums } \\
(\% \text { GDP })\end{array}$ & $\begin{array}{l}9.25688 * * \\
(3.00472)\end{array}$ & $\begin{array}{l}6.7150 * * * \\
(1.829)\end{array}$ & $\begin{array}{l}6.0995 * * * \\
(2.0459)\end{array}$ & $\begin{array}{l}4.4002 \\
(2.7485)\end{array}$ & $\begin{array}{l}12.8772 * * \\
(4.9878)\end{array}$ & $\begin{array}{l}9.3368 * * * \\
(3.1960)\end{array}$ & $\begin{array}{l}8.5805 * * * \\
(2.9793)\end{array}$ & $\begin{array}{l}4.58200 \\
(4.7798)\end{array}$ \\
\hline Initial GDP per capita & $\begin{array}{l}0.00196^{*} \\
(0.00101) \\
\end{array}$ & $\begin{array}{l}0.00146 \\
(0.0011) \\
\end{array}$ & $\begin{array}{l}0.00151 \\
(0.0012) \\
\end{array}$ & $\begin{array}{l}0.000475 \\
(0.0029) \\
\end{array}$ & $\begin{array}{l}0.00141 \\
(0.0014)\end{array}$ & $\begin{array}{l}0.00111 \\
(0.0014) \\
\end{array}$ & $\begin{array}{l}0.00155 \\
(0.0012) \\
\end{array}$ & $\begin{array}{l}0.00451 \\
(0.00575) \\
\end{array}$ \\
\hline Investment & & $\begin{array}{l}0.00322 \\
(0.5959)\end{array}$ & $\begin{array}{l}0.00318 \\
(0.6101)\end{array}$ & $\begin{array}{l}1.9460 * * \\
(0.85609)\end{array}$ & & $\begin{array}{l}-0.4912 \\
(0.8115)\end{array}$ & $\begin{array}{l}-0.4688 \\
(0.6050)\end{array}$ & $\begin{array}{l}2.6225 * * * \\
(0.9291)\end{array}$ \\
\hline $\begin{array}{l}\text { Private credit }(\% \\
\text { GDP) }\end{array}$ & & $\begin{array}{l}0.511677 * * \\
(0.22554)\end{array}$ & $\begin{array}{l}0.60685^{* *} \\
(0.2739)\end{array}$ & $\begin{array}{l}1.4850 * * * \\
(0.3392)\end{array}$ & & $\begin{array}{l}0.64153^{* *} \\
(0.2686)\end{array}$ & $\begin{array}{l}0.67568 * * \\
(0.3157)\end{array}$ & $\begin{array}{l}1.7010 * * * \\
(0.5261)\end{array}$ \\
\hline Inflation & & $\begin{array}{l}-0.00316 \\
(0.1334) \\
\end{array}$ & & $\begin{array}{l}-0.0105 \\
(0.0111) \\
\end{array}$ & & $\begin{array}{l}0.06012 \\
(0.1684)\end{array}$ & & $\begin{array}{l}-0.030254 \\
(0.02620)\end{array}$ \\
\hline Real interest rate & & & $\begin{array}{l}0.05994 \\
(0.22091) \\
\end{array}$ & & & & $\begin{array}{l}0.0504 \\
(0.2047)\end{array}$ & \\
\hline FDI & & & & $\begin{array}{l}-0.036891 \\
(3.1711) \\
\end{array}$ & & & & $\begin{array}{l}-6.66160 \\
(9.3777)\end{array}$ \\
\hline Constant & $\begin{array}{l}-0.6175 \\
(5.197) \\
\end{array}$ & $\begin{array}{l}-13.0978 \\
(11.0072) \\
\end{array}$ & $\begin{array}{l}-15.951 \\
(11.963) \\
\end{array}$ & $\begin{array}{l}0.980373 \\
(15.3158) \\
\end{array}$ & $\begin{array}{l}-4.82999 \\
(7.32192) \\
\end{array}$ & $\begin{array}{l}-11.328 \\
(16.9528) \\
\end{array}$ & $\begin{array}{l}-12.1548 \\
(12.0212) \\
\end{array}$ & $\begin{array}{l}19.46035 \\
(22.7626) \\
\end{array}$ \\
\hline $\begin{array}{l}\text { Observations } \\
\text { Countries } \\
\operatorname{AR}(1): p \text {-value } \\
\operatorname{AR}(2): \text { p-value } \\
\text { Hansen OID test: } \\
\text { prob. } \\
\text { Instruments }\end{array}$ & $\begin{array}{l}125 \\
37 \\
0.041 \\
0.166 \\
0.217 \\
24\end{array}$ & $\begin{array}{l}121 \\
36 \\
0.026 \\
0.124 \\
0.280 \\
26\end{array}$ & $\begin{array}{l}104 \\
33 \\
0.057 \\
0.143 \\
0.458 \\
27\end{array}$ & $\begin{array}{l}121 \\
36 \\
0.086 \\
0.496 \\
0.217 \\
27\end{array}$ & $\begin{array}{l}88 \\
36 \\
0.046 \\
0.185 \\
0.332 \\
15\end{array}$ & $\begin{array}{l}85 \\
35 \\
0.036 \\
0.153 \\
0.230 \\
17\end{array}$ & $\begin{array}{l}74 \\
33 \\
0.071 \\
0.153 \\
0.146 \\
18\end{array}$ & $\begin{array}{l}85 \\
35 \\
0.122 \\
0.885 \\
0.678 \\
18\end{array}$ \\
\hline
\end{tabular}

Note. The estimation method is the two-step System-GMM method with the Windmeijer (2005) correction for finite sample bias. Robust standard errors are reported in parentheses. AR (1): and AR (2): denote the Arellano and Bond statistics tests for lack of one-order and second-order serial correlation, respectively $* \mathrm{P}<0.1, * * \mathrm{p}<$ $0.05, * * * \mathrm{p}<0.01$. All the variables of the model are assumed to predetermined and instrumented by their delays at most 5 periods

The results in Table 4 show that our basic results are robust to use of alternative measure of the development of stock market. The coefficient of insurance penetration is positive and significant in all the regressions during the period 1987-2011 and period before financial crisis (1987-2006). This suggests a substantial economic effect of the development of insurance sector on stock market development. Thus, ceteris paribus, an increase of $0.1 \%$ unit of standard deviation of insurance penetration leads to an increase in stock market capitalization of $28.173 \%$ (column 3). Moreover, using stock market capitalization to GDP as 
proxy for stock market development, the positive effect of domestic investment on stock market remains significant (column 4 and 8). The initial GDP per capita and private credit has a positive and significant effect on stock market capitalization while inflation, real interest rate, and FDI have not a significant effect on stock capitalization.

\section{Conclusion}

This paper has analyzed impact of insurance premiums on the development of stock market from a sample of 37 developing countries over period from 1987 to 2011. Thus, it is using of the econometric estimates technique (System GMM) which allows take into account potential endogeneity of insurance premiums. The results show that when the insurance premiums increase, stock transaction also increases. The positive impact of insurance penetration is robust to control legal system quality and to use of alternative measure of stock market development. Thus, insurance development creates necessary atmosphere for the development of stock market. Furthermore, legal system quality such as protection of property rights is a significant determinant of stock market deepening.

The conclusions of this paper have policy implications for developing countries. Given the evidence that insurance has a positive relationship with the development of stock markets, the developing countries should undertake of the policies that aim to encourage insurance development (especially life insurance); which will allow to insurance companies to mobilize significant stable resources for finance the economy through purchase of financial assets. In addition, the conclusions on legal system quality suggest that an improvement of legal framework, in particular the improvement of property rights is necessary for a country to obtain the full benefits of insurance development on stock market.

\section{References}

Arellano, M., \& Bond, S. (1991). Some tests of specification for panel data: Monte Carlo evidence and an application to employment equations. The Review of Economic Studies, 277-297. http://dx.doi.org/10.2307/2297968

Arellano, M., \& Bover, O. (1995). Another look at the instrumental variable estimation of error components models. Journal of Econometrics, 68(1), 29-51. http://dx.doi.org/10.1016/0304-4076(94)01642-D

Arena, M. (2008). Does insurance market activity promote economic growth? A cross-country study for industrialized and developing countries. Journal of Risk and Insurance, 75(4), 921-946. http://dx.doi.org/10.1111/j.1539-6975.2008.00291.x

Avram, K., Nguyen, Y., \& Skully, M. (2010). Insurance and economic growth: A cross country examination. Working Paper, Monash University.

Beck, T., \& Levine, R. (2004). Stock Markets, Banks and Growth: Panel Evidence. Journal of Banking and Finance, 423-442. http://dx.doi.org/10.1016/S0378-4266(02)00408-9

Beck, T., \& Webb, I. (2003). Economic, demographic, and institutional determinants of life insurance consumption across countries. World Bank Economic Review, 17(I), 51-88. 
http://dx.doi.org/10.1093/wber/lhg011

Blundell, R., \& Bond, S. (1998). Initial conditions and moment restrictions in dynamic panel data models. Journal of econometrics, 87(1), 115-143. http://dx.doi.org/10.1016/S0304-4076(98)00009-8

Boyd, J. H., Levine, R., \& Smith, B. D. (2001). The Impact of Inflation on Financial Sector Performance. Journal of Monetary Economics, 47(2), 221-248. http://dx.doi.org/10.1016/S0304-3932(01)00049-6

Catalan, M., Impavido, G., \& Musalem, A. R. (2002). Contractual savings or stock market development which leads? Unpublished Policy Research Working Paper No. 2421.The World Bank.

Chang, C. H., \& Lee, C. C. (2012). Non-Linearity between Life Insurance and Economic Development: A Revisited Approach. The Geneva Risk and Insurance Review, 37, 223-257. http://dx.doi.org/10.1057/grir.2011.10

Čihák, M., Demirgüç-Kunt, A., Feyen, E., \& Levine, R. (2012). Benchmarking Financial Systems around the World. Policy Research Working Paper 6175.

Claessens, S., \& Laeven, L. (2003). Financial development, property rights, and growth. Journal of Finance, 58(6), 2401-2436. http://dx.doi.org/10.1046/j.1540-6261.2003.00610.x

Dickinson, G. (2000). Encouraging a dynamic life insurance industry: Economic benefits and policy issues. Center for insurance and investment studies, London.

Garcia, F. V., \& Liu, L. (1999). Macroeconomic Determinants of Stock Market Development. Journal of Applied Economics, 2(1), 29-59.

Impavido, G., \& Musalem A. R. (2000). Contractual Savings, Stock and Asset Markets. World Bank Policy Research Paper: 2490.

Impavido, G., Musalem, A. R., \& Tressel, T. (2003). The impact of contractual savings institutions on securities markets. Unpublished Policy Research Working Paper No. 2948. http://dx.doi.org/10.1596/1813-9450-2948

La Porta, R., Lopez-de-Silanes, F., Shleifer, A., \& Vishny R. W. (1998). Law and Finance. Journal of Political Economy, 106, 1113-1150. http://dx.doi.org/10.1086/250042

La Porta, R., Lopez-de-Silanes, F., Shleifer, A., \& Vishny, R. W. (1997). Legal determinants of external finance. Journal of Finance, 52(3), 1131-1150. http://dx.doi.org/10.1111/j.1540-6261.1997.tb02727.x

Levine, R., \& Zervos, S. (1998). Stock markets, banks and economic growth. American Economic Review, 88(3), 537-558.

Masci, P., Tejerina, L., \& Webb, I. (2007). Insurance Market Development in Latin America and the Caribbean. Inter-American Development Bank No. IFM-146.

OECD. (2004). Developing Life Insurance in the Economies in Transition. 
OECD. (2014). Development Co-operation Report 2014: Mobilising Resources for Sustainable Development. OECD Publishing.

Outreville J. F. (2011). The Relationship Between insurance Growth and Economic Development: 80 Empirical Papers for a Review of the Literature. Working Paper No.12. http://dx.doi.org/10.2139/ssrn.1885401

Pagano, M. (1993). Financial Markets and Growth: An Overview. European Economic Review, 37(1), 613-622. http://dx.doi.org/10.1016/0014-2921(93)90051-B

Roodman, D. (2009a). How to do xtabond2: An introduction to difference and system gmm in stata. Stata Journal, 9(1), 86-136.

Roodman, D. A. (2009b). Note on the theme of too many instruments. Oxford Bulletin of Economics and Statistics, 71(1), 135-158. http://dx.doi.org/10.1111/j.1468-0084.2008.00542.x

UNCTD. (1982). The promotion of life insurance in Developing countries study. Trade and Development Board Committee on Invisible and Financing related to Trade Trenth session.

Vittas, D. (1998b). Institutional Investors and Securities Markets: Which Comes First? The World Bank, Policy Research Working Paper Series, No. 2032.

Ward, D., \& Zurbruegg, R. (2000). Does insurance promote economic growth? Evidence from OECD countries. Journal of Risk and Insurance, 67(4), 489-506. http://dx.doi.org/10.2307/253847

Webb, I., Grace, M. F., \& Skipper, H. D. (2002). The effect of banking and insurance on the growth of capital and output. Unpublished Center for Risk Management and Insurance Working Paper 02-1. Georgia State University, GA.

Windmeijer, F. (2005). A finite sample correction for the variance of linear efficient two-step GMM estimators. Journal of econometrics, 126(1), 25-51. http://dx.doi.org/10.1016/j.jeconom.2004.02.005

Yartey, C. A. (2008). The determinants of Stock Market Development in Emerging Economies: Is South Africa Different? IMF Working Paper No.08/32.

\section{Notes}

Note 1. UNCTAD (United Nations Conference on Trade And Development) is an organ of the United Nations whose objective is (a) to reduce and eventually eliminate the trade gap between the developed and developing Countries, and (b) and to accelerate the rate of economic growth of the developing world.

Note 2. The time dimension and Countries were selected mainly by data availability for period of our study. One a common problem encountered in empirical research on insurance premiums is finding data covering a long time dimension especially for developing countries. 
Note 3. These variables are used interchangeably in the regressions. The Legal System and Property Rights, measure of the quality of a country's legal system and protection of property rights is from the Economic Freedom of the World Index, Fraser Institute.

Note 4. Too many instruments may over fit endogenous variables leading to a failure in expunging their endogenous components.

Note 5. Our 37 sample of developing countries in alphabetical order are Argentina, Bangladesh, Bolivia, Botswana, Brazil, China, Colombia, Costa Rica, Cote d'Ivoire, Ecuador, Sri Lanka, El Salvador Egypt. Arab Rep., Fiji, Ghana, India, Iran. Islamic Rep., Jamaica, Jordan, Kazakhstan, Kenya, Latvia, Malaysia, Malta, Mauritius, Mexico, Monaco, Nigeria, Pakistan, Panama, Peru, Philippines, Singapore, South Africa, Thailand, Tunisia, Zambia.

Note 6. The diagnostic statistics are favorable. The Hansen test of overidentification, which is robust to heteroscedasticity, does not reject the validity of instrumental variables used and the Arellano and Bond test rejects the second order serial correlation.

UNCTAD (United Nations Conference on Trade And Development) is an organ of the United Nations whose objective is (a) to reduce and eventually eliminate the trade gap between the developed and developing Countries, and (b) and to accelerate the rate of economic growth of the developing world.

The time dimension and Countries were selected mainly by data availability for period of our study. One a common problem encountered in empirical research on insurance premiums is finding data covering a long time dimension especially for developing countries.

These variables are used interchangeably in the regressions. The Legal System and Property Rights, measure of the quality of a country's legal system and protection of property rights is from the Economic Freedom of the World Index, Fraser Institute.

Too many instruments may over fit endogenous variables leading to a failure in expunging their endogenous components.

Our 37 sample of developing countries in alphabetical order are Argentina, Bangladesh, Bolivia, Botswana, Brazil, China, Colombia, Costa Rica, Cote d'Ivoire, Ecuador, Sri Lanka, El Salvador Egypt. Arab Rep., Fiji, Ghana, India, Iran. Islamic Rep., Jamaica, Jordan, Kazakhstan, Kenya, Latvia, Malaysia, Malta, Mauritius, Mexico, Monaco, Nigeria, Pakistan, Panama, Peru, Philippines, Singapore, South Africa, Thailand, Tunisia, Zambia.

The diagnostic statistics are favorable. The Hansen test of overidentification, which is robust to heteroscedasticity, does not reject the validity of instrumental variables used and the Arellano and Bond test rejects the second order serial correlation. 


\section{Copyright Disclaimer}

Copyright for this article is retained by the author(s), with first publication rights granted to the journal.

This is an open-access article distributed under the terms and conditions of the Creative Commons Attribution license (http://creativecommons.org/licenses/by/3.0/). 